\title{
Expanding Pre-Service Teachers' Conceptions of Texts, Readers, and Response Through Multimodal Response
}

\author{
TED KESLER \\ Queens College, City University of New York
}

\begin{abstract}
The author conducted a qualitative study of multimodal digital response to children's historical fiction that his 23 pre-service graduate students read in book clubs. Grounded in sociocultural and multimodal theories of literacy, the study addresses the following two research questions: What influence did sociocultural and multimodal engagements with text have on students' meaning-making? What influence did these engagements have on their conceptions of texts, readers, and response? Findings show how social negotiation of meaning and robustness of design work expanded participants' understandings of texts, readers, and response that challenge current autonomous, verbocentric conceptions of literacy that predominate in schools.
\end{abstract}

My pre-service teachers were over-relying on written responses to literature as the single mode of expression in all their lesson plans in the first few months of my language arts methods course. It was ingrained in them from their own schooling and it matched their conception of text as words on a page. Literacy was a set of neutral, skills-based competencies, autonomous of context, determined by academic performance. They imagined a solitary reader, and a reader's job, they maintained, was to decode the words, figure out the author's message, and make personal connections. This conception was expressed in lessons I observed in their student teaching. Some typical examples were: in first grade, after reading The Snowy Day (Keats, 1962), asking "what are some things you like to do in the snow?"; in third grade, after reading The Other Side (Woodson, 2001), asking "what meaning did the fence have in the story?"; and, in fifth grade, after reading Thank You, Mr. Falker (Polacco, 1998), asking "what are some ways that Mr. Falker helped Trisha?" These response questions were also consistent with what is expected of students for their written responses on the state English language arts test. My students were often frustrated in their urban, high-needs elementary school placements by students who gave sparse responses, resisted the assignment, or were reluctant writers.

This study arose from my desire to expand my students' conceptions of texts, readers, and response. First, I wanted my students to perceive a much broader definition of texts. Texts are part of a "sign complex formed by print and other communication systems in relation to situational context" (Harste, Woodward, \& Burke, 1984, p. 169). This definition aptly describes the multimedia texts that I intended the graduate students to create in this study. While most texts use the written mode, many are also multimodal, especially if they are on electronic screens: in addition to writing, they might include other symbol systems, drawings, charts or graphs, animations, soundtracks. Even the choice of font, the use of colors, special print, and layout convey important meaning in the overall coherence of the text. Second, I wanted my students to realize the sociocultural dynamics of reading. Even when they read privately, the meanings they construct are based in the social networks they are engaged in. Third, I wanted them to experience multimodal forms of response that deepen their overall engagement with and 
interpretation of texts. I felt these expanded understandings were imperative for meeting the needs of the diverse students they would teach (Siegel, 2006; Whitin, 2005). In short, I believed that engaging in social interactions for reader response using multiple sign systems would strongly prepare my students for their work with children.

\section{Sociocultural Theory, Multimodality, and Reader Response}

Sociocultural theories emphasize that textual meaning is constructed by individuals through social interactions (Vygotsky, 1962; 1978). John-Steiner and Meehan (2000) discuss Vygotsky's conception of complementarity, which is central to a collaborative co-construction of knowledge that they call cognitive pluralism. "Complementarity implies mutual internalization, a making into one's own some aspect of one's partner's knowledge” (p. 45). Lave and Wenger (1992) remind us, "learning is an integral part of generative social practice in the lived-in world" (p. 35). Thus, learning occurs among co-participants as they engage with artifacts in a learning context, not in an individual mind, leading to social transformation. Vygotsky explicated the power of artifact-mediated joint activity for the transformation of participants and settings over time. He stated, "Human learning presupposes a specific social nature and a process by which children grow into the intellectual life of those around them" (1978, p. 88). This statement is just as true for adult learners in new learning situations. For Vygotsky, language was a central mediating mode for the learning process.

Multimodal theorists lament the centrality of language in traditional school settings. Kress (2000) states: "The single, exclusive and intensive focus on written language has dampened the full development of all kinds of human potentials" (p. 156). This statement aptly expresses my concern that generated this study. In addition to language, multimodal theory encompasses multiple sign systems such as mathematics, dance, drama, art, music, and increasingly, the myriad affordances of digital technologies. Each of these sign systems represents new possibilities to construct meaning. Siegel (1995) explains: "each sign system is based on a unique organizational principle and involves elements that have no ready equivalents in the other sign system" (p. 458). Since each sign system expresses particular possibilities and limitations, there is no direct correspondence between a linguistic text and any sign system. Readers must think critically and be inventive as they use a sign system to represent meaning. Moreover, as they work across sign systems, in a process called transmediation, readers generate new meanings and gain new interpretive levels for the text. In transmediation, learners transform understanding by building connections that map the content of one sign system onto the expressive plane of another through metaphorical associations (Siegel, 1995; 2006). Since sign making exists for communication, this generative potential only has power within sociocultural contexts (Kress, 2003). In summary, transformative possibilities in both sociocultural and multimodal theories guided me to design a study in which my students would engage multimodally in authentic social activity.

\section{Multimodal Reader Response}

This study contributes to the literature on reader response and in particular multimodal reader response. One of the most prominent reader response theories is transactional reading theory. Rosenblatt (1994) explains that all reading experiences are transactions between a reader and a text in a particular context. All readers mediate between the symbols of a text and their referents in the world to construct a coherent whole, the world of the text, by adopting selective attention, or a stance, along an aesthetic to efferent continuum. In an efferent stance, the reader's 
attention is directed outward towards what he will take away from the reading experience - "the information, the concepts, the guides to action, that will be left with him when the reading is over" (p. 27). In an aesthetic stance, the reader's attention is directed inward toward her livedthrough experience during the reading of a particular text - "the chiming of sound, sense, idea, and association" (p. 26). Since the transaction depends on a reader's stance, "each encounter between a reader and the text is a unique event" (pp. 35-36). Within a community of readers, each person's unique transaction with the text invites multiple interpretations. Meanings are not static; rather, they evolve through interaction (Probst, 1994). Moreover, the same text may be recreated by the same reader, in different contexts, as both an efferent and an aesthetic experience. This range of experiences with one text is what I aimed to provide my students in the design of this study.

Ample classroom research on multimodal reader response shows its transformative potential for students' learning. Numerous researchers have documented the generative and interpretive capacities as students of all ages engaged in art, music, drama, dance, and multimedia in response to texts (Ballentine \& Hill, 2000; Clyde, 2003; O’Brien, 2001; Short, Kauffman, Kahn, 2000; Whitin, 1996; 2005; Wilhelm, 2008). Ballentine and Hill (2000) used ongoing whole class and small group conversations and responses in art and drama to deepen students' comprehension of challenging literature. Whitin (2005) taught her fourth grade students the transactional reading strategy, sketch-to-stretch (Short \& Harste, 1986). She discovered that, working in groups, students used their sketches not as end-products in themselves, but as meditational tools for thinking more deeply about texts through exploratory talk with others. In addition, she reported the importance of students' collaborative, exploratory talk as an integral part of their transmediation process or what she termed "socially negotiated transmediation" ( $p$. 391). Clyde (2003) discovered that using visualization and drama, in a strategy she called "the subtext strategy," built students' personal connections, inferencing, empathy for characters, and abilities to consider multiple perspectives in texts. In O'Brien (2001) and Wilhelm's (2008) studies, multimodal response repositioned adolescent low-achieving and/or "at-risk" students as competent and successful by expanding what counts as literacy and literate behavior. O'Brien (2001) achieved his results by providing digital technology and resources for his students' multimodal responses. All these researchers' findings bolstered my commitment to using multiple modes, including the multimedia of digital technology, for my students' responses to challenging literature.

Larson (2008) reported on a conceptual framework that she called Electronic Reading Workshop (ERW), based on the framework of reading workshop, for her pre-service undergraduate students. ERW enabled opportunities for new literacy practices and integration of technology. Using computer technology, each group created an original multimedia response to a common class text. Group responses included: a virtual guide to the novel using PowerPoint, a digital oral history that connected the students' own diverse family histories with the immigrant story in the novel, a newspaper project based in the novel's historical setting, a podcast to simulate the sights and sounds of a live broadcast of the novel's historical setting, among others. All responses depended on social learning experiences and showed the generative potential of digital technologies for transactional reading. By the end of the study, Larson's students were much better positioned to bring these practices to their future elementary school-aged students.

While digital storytelling and moviemaking are now well-documented practices in schools, few studies document the use of this digital media for reader response. Digital stories are multimedia texts consisting of still images, soundtrack, narration, transitions, print, and 
perhaps video. Digital stories provide affordances of aural, oral, visual, linguistic, temporal, and written modes. The overall design of digital stories requires the layering of these modes in ways that intensify the intended messages (Siegel, 2006). Moreover, the composing process for digital stories utilizes both foundational and new literacies (Skinner \& Hagood, 2008; Sylvester \& Greenidge, 2009). Some researchers report the powerful contribution of a community of learners in a workshop setting for digital storytelling (e.g., Brass, 2008; Hull \& Katz, 2006; Sylvester \& Greenidge, 2009). Burgess (2006) describes "the strong affective resonances created by the warmth and visceral presence of the narrator's voiceover" in a digital story (p. 210). Thus, digital storytelling has strong possibilities for multimodal reader response, and seems to favor an aesthetic stance. However, most studies of digital storytelling report on the process of individuals representing themselves in self-generated, highly personal stories (e.g., Brass, 2008; Hull \& Katz, 2006; Ohler, 2005/2006; Skinner \& Hagood, 2008; Sylvester \& Greenidge, 2009).

Whitin (2009) presented a case study of her pre-service graduate students in which she analyzed what they learned about modes of expression and how they developed proficiency in using these modalities, culminating in digital movies, to interpret text. Specifically, her students responded to Through My Eyes (Bridges, 1999), a non-fiction picture book about Ruby Bridges' experiences as the lone African American girl to desegregate a New Orleans public school in 1960. Whitin took her students through a three-phase process. They first learned to recognize multimodality in picture books, then, working in groups, applied these understandings to Through My Eyes, and finally created digital movies about their insights, using a process that Whitin called "tech-to-stretch." This term recalls visual transactional reading strategies such as sketch-to-stretch, while also calling forth all the other multimodal affordances of digital technology. Whereas digital stories are arranged temporally, the tech-to-stretch responses did not have to be. By applying the many affordances of digital responses in aural, visual, verbal, and animation modes, in a process of transmediation, Whitin's students expressed transformed meanings of the text. Whitin discovered that her students had "heightened levels of comprehension" (p. 417) as a result of these multimodal engagements. As will be explained below, the design of my study differs in several ways from Whitin's. My study also relies on the temporal arrangement of digital storytelling as a basis for response. Moreover, my study focuses on the sociocultural, as well as multimodal, dimensions of reader response, and on the expanded insights that my students experienced about texts, readers, and response as a result of this work. My study answers the following two research questions: (a) What influence did sociocultural and multimodal engagements with text have on students' meaning-making? (b) What influence did these engagements have on their conceptions of texts, readers, and response?

\section{The Study Design}

To enable new experiences with reader response, I designed a study that required my students to interact socially to generate meaning and construct responses that were multimodal texts. The participants were 23 graduate students who were in a 14-month cohort pre-service program at an urban public college in the Northeast. The study occurred in the spring semester of our two-course sequence. Therefore, the students knew each other and me quite well at the start of this study and the audience of their peers mattered to them.

To maintain the status quo relationships with my students, all activities and data collection methods were conceived and presented as ongoing activities that were woven into the course syllabus. As a teacher-research study, I was deeply invested in the quality of the work we did. Many of the transactional reading strategies that I describe below were also consistent with 
our fall semester work. A colleague who also taught this cohort of students but was not involved in the study administered the consent forms. She held these forms until several weeks after the semester ended, just before Phase III of the study was to begin and the participants were no longer officially my students. Thus, during the study, I had no idea who did or did not give consent. Students consented to my use of the data for dissemination and to being interviewed in Phase III of the study. The study had three phases so that I could document the students' social interactions and use of multiple modes to interpret literature (Figure 1).

Figure 1. The Design Sequence of the Study.

\begin{tabular}{|l|l|l|}
\hline $\begin{array}{l}\text { Study of Book Club } \\
\text { Texts } \\
\text { Use of reading } \\
\text { response notebooks }\end{array}$ & $\begin{array}{l}\text { Digital Movie Composition } \\
\text { Dook Club } \\
\text { discussions } \\
\begin{array}{l}\text { Information seeking } \\
\text { inquiry }\end{array}\end{array} \mid \begin{array}{l}\text { Develop synthesized } \\
\text { interpretation by using } \\
\text { representational resources: } \\
\text { aural, oral, visual, temporal, } \\
\text { and written responses } \\
\text { ("tech-to-stretch") (Whitin, } \\
\text { 2009) }\end{array}$ & $\begin{array}{l}\text { Semi- } \\
\text { structured } \\
\text { interviews } \\
\text { and } \\
\text { retrospective } \\
\text { accounts } \\
\text { with seven } \\
\text { focal } \\
\text { students }\end{array}$ \\
\hline Phase I
\end{tabular}

In Phase I, the students participated in one of five book clubs for their choice of the following historical fiction texts: ... and now Miguel (Krumgold, 1953), Elijah of Buxton (Curtis, 2007), Jim the Boy (Earley, 2000), Al Capone Does My Shirts (Choldenko, 2004), and Billy Creekmore (Porter, 2007). These texts were chosen for several reasons. First, they are used widely for integrated language arts and social studies curriculum in upper elementary and middle school grades, which was the focus of our second semester. Second, these texts meet several of the criteria Fountas and Pinnell (2001, p. 263) use to determine texts for use in book clubs (Raphael \& McMahon, 1994). For example, they include layers of meaning, exemplify worthwhile issues, reflect a variety of perspectives, and represent our diverse world. Throughout the semester, I gave explicit instruction in transactional reading strategies using a reading response notebook with a whole class read-aloud text, J.T. (Wagner, 1969). Responses included sketch-to-stretch, stop and jot, two-sided entries, representational sketches, character web of relationships, representing character relationships mathematically, diagrams, and creating text sets, among others. The students then used their notebooks to prepare for and facilitate their book club discussions. 
The book clubs met three times in class for 20 minute discussions, followed by the groups processing their work and planning and preparing for their next meeting. Lindfors (1999) describes two broadly defined types of inquiry: information seeking and wondering. Information seeking involves seeking clarification, justification, explanation, or confirmation of questions that arise from transactions with text. Wondering involves predicting, reflecting, exploring, and considering possibilities that arise in discussion with others. Wondering happened through the students' reading response notebooks and the exploratory talk of their book club discussions, and emphasized an aesthetic stance towards the text. After the third meeting, I prepared the groups for information-seeking inquiry by considering lingering questions that they might be able to find answers to through research. For example, the Elijah of Buxton group wanted to investigate the rules and physical features of the Buxton settlement and its geographical location to key events in the text. Thus, this inquiry work took an efferent stance towards the text. Group members began gathering resources and investigating their questions for homework. In our next class session, groups consolidated and discussed their findings, did more exploration, and prepared a presentation to the class. Data sources from this phase included observing the students during book club and inquiry discussions, and analyzing their reading response notebooks and inquiry presentations. This work lasted five weeks and laid the groundwork for Phase II.

For Phase II of the study, I collaborated with Lucia ${ }^{1}$, the technology instructor for the students' required course in using technology in classrooms, and became a participant observer in the class. As part of our collaboration, the culminating assignment in the technology class became a digital story (or digital movie) in response to their book club text for an audience of their peers. Thus, similar to Whitin's (2009) term "tech-to-stretch," I conceived sociallynegotiated digital storytelling for students' collaborative work to create a multimodal, transactional digital response to their book club texts.

For Lucia, building the students' confidence and facility with the use of PowerPoint was one of her course objectives. She believed that PowerPoint was accessible and had many practical applications in schools. Moreover, in an informal technology questionnaire that Lucia administered at the start of the semester, we discovered that 18 of the 23 students rated themselves as novice to average users of PowerPoint and requested more instruction with this software. Therefore, although PowerPoint has more constraints and fewer affordances as movie making software than, for example, iMovie, Movie Maker, or Photostory, we agreed to use it as the medium for the students' digital design work. Our collaboration enabled integration of technology and literacy consistent with the literature (Leu, O'Byrne, Zawilinski, McVerry, and Everett-Cacopardo, 2009; Smolin \& Lawless, 2003; Young \& Bush, 2004). Typically, the technology class focused on learning from and about technology. For this assignment, technology would be an integral tool that students would learn as needed as they engaged in a meaningful literacy project. Thus, this tech-to-stretch project might enhance literacy instruction in the ways I intended.

To prepare for their digital stories, Lucia and I showed them an example that we created for the book Just Juice (Hesse, 1998), and co-constructed criteria that became the checklist for their work and their final assessment (Appendix A). We discussed and charted a possible sequence. We gave the students storyboard templates (Appendix B), which became the outlines for their digital stories, and they had time in both their technology and literacy classes to work. Data sources for this phase included analysis of their storyboards and their digital stories, observing their work process, and keeping a field notebook for observational notes and

\footnotetext{
${ }^{1}$ All names are pseudonyms.
} 
reflections. Work sessions in both classes were video and audio recorded for analysis. This phase occurred during five weeks of the technology class, in addition to two work sessions in my literacy class.

In Phase III, a few weeks after the end of the semester, I conducted semi-structured interviews (see Appendix $\mathrm{C}$ for interview questions) with seven of my graduate students and engaged in retrospective accounts in which we viewed their digital stories and I asked them to talk through the process of creating them. Three of the students were from the Elijah of Buxton group (the fourth student in this group, while consenting to the use of all data from the group, did not consent to being interviewed). Two students were from the Jim the Boy group and two were from the ... and now Miguel group. I selected these students because they represented the diversity of the cohort in terms of race, ethnicity, age, and status as parents, and in their level of comfort with and knowledge of technology. In the guiding questions of my semi-structured interviews, I pursued three broad categories: (a) ways the multimodal experience of digital storytelling may have intensified the students' intended messages (Siegel, 2006); (b) ways that the collaborative nature of this project may have contributed to sociocultural understandings of reading; (c) ways that this collective experience may have shifted the students' thinking about texts, readers, and response. Each session was audio recorded and later transcribed.

I used grounded theory (Merriam, 2001; Miles \& Huberman, 1994) to examine the transcripts. I coded them based in sociocultural and multimodal theories, which I categorized. Some codes included dissension, taking on roles, comprehension, multiple perspectives, and exploratory talk, which I categorized as social negotiation of meaning. Another set of codes included materials, affordances, transmediation, audience, and purpose, which I categorized as design work. Following the constant comparative method (Charmaz, 2000; Glaser \& Strauss, 1967), I reexamined data from the first two phases that delineated and challenged these categories, which enabled me to develop emergent themes. Since three of the focal students came from the Elijah of Buxton group, for this paper, I looked specifically at this case as an exemplar (Stake, 2000). I analyzed all video footage of this group's work for further delineation and challenges to the emergent themes. In other words, my analysis revealed the multimodality of mediated action (Kress \& van Leeuwen, 2001) and the dynamics of social interactions that may have contributed to meaning-making. In the next section, I describe the Elijah of Buxton group and the work they did. I then present the findings for this group in the two categories that I stated above, which follow the design of the study. Next, I discuss how this joint activity shifted the participants' understandings of texts, readers, and response. I conclude with a discussion of the findings in relation to the theories that frame this study, limitations, and implications.

\section{The Elijah of Buxton Group}

The Elijah of Buxton group had four members, all in their twenties, representing the diversity of the students in the pre-service cohort, who were all women. Catherine was IrishAmerican. Saleema was a devout Muslim originally from Pakistan, who grew up in Canada, and came to New York for her husband's work. Mirjana was born in New York City, returned to Serbia with her parents when she was an infant, then moved back to the U.S.A. two years later. Dahlia was a first-generation American of Haitian parents of African descent. She was married and had a five-year-old son in kindergarten at the time of this study. As the findings will show, their social and cultural backgrounds figured largely in the group's joint construction of meaning. They all rated themselves as average computer users. Mirjana and Catherine knew no 
PowerPoint at the start of this study, and Saleema and Dahlia considered themselves to have basic understandings of this software.

For their digital story, the group decided to focus on the climactic episodes in the book when twelve-year-old Elijah travels to a village near Detroit, Michigan on horseback to redeem his friend Mr. Leroy's money from the Preacher. That night in a stable, he discovers the Preacher's brutalized body, but also a group of runaway slaves - a woman named Chloe, her African husband, their baby, two other African men, and one African boy - who have been captured and chained and will be sent back down South in the morning. Elijah rescues the baby, gives her the name Hope, and takes her to Buxton, the Black settlement in Canada where Elijah was the first free-born child. In narrative structure, these episodes represent the crisis, the climax, and the denouement of the story that lead to Elijah's transformation. The group focused on the scene in the barn. They drew and painted all the images for this scene. Their digital story included sound effects such as a galloping horse, crickets, a hooting owl, a creaking stable door, and the rattling of chains to depict the setting. In one slide, Dahlia hummed a tune to replicate an old Negro Spiritual. They used theme music from three movies: "Once," "3:10 to Yuma," and "I Am Legend." They used captions and one book excerpt. They used Elijah's first person narration, and extensive dialogue between Elijah and Chloe. As I will discuss, the group made extensive design decisions, including elements such as layout, font, color, voice, and transitions.

\section{The Social Negotiation of Meaning}

The group's social negotiation of meaning began with their book club meetings. They each expressed strong personal connections to the characters, themes, and issues in the story, so shared meaning construction mattered. Dahlia expressed these deep personal connections that played out in their book club sessions. In a scene in the middle of the book, Elijah's mother, Sarah, tells the story of her own passage to freedom. When Sarah's mother discovered that Sarah was on the banks of Lake Erie one summer, at the age of 12, with the family that owned her, in sight of Canada, and didn't escape to her freedom, her mother beat her and warned her, "If you get another chance and don't take it... or die trying...I swear, girl, I'll kill you myself once you get back here" (Curtis, 2007, p. 211). Two years later, Sarah got the chance and never saw her mother again. In the following exchange between researcher and participant, Dahlia describes her response to this scene ${ }^{2}$.

Dahlia: There were a lot of scenes, that, sometimes I felt, um, this is speaking for myself: sometimes I felt that, um, my group members didn't realize how telling the scenes were. And I don't know if it was 'cause I'm from Afr...I'm from slaves, so for me, a lot of the book was, like, “Oh, my gosh!" Like I see myself in this book, I see my mother, I see my family members running, and sometimes I felt that my group members didn't realize. So, during the group part, I would talk to them about it. I'd say, "Imagine, you were being pulled away from your mom, and your mother beating you, because you didn't run away, with when Elijah's mom said the story about how close she got to Canada, and she didn't run, and her mother...

Researcher: Incredible story, wasn't it?

Dahlia: Yeah. And they almost went over it, they didn't really understand it...That [scene] was horrible, and that was everyone's reality.

\footnotetext{
${ }^{2}$ In all excerpts of transcripts, bold print indicates overlapping speech; underline indicates emphasis; [words in brackets] indicates my commentary for clarification; ["words in brackets"] indicates interjections.
} 
Researcher: So, you had deep personal connections.

Dahlia: Yesss! So, I think group discussions were very helpful.

Dahlia recognized deeply-held social, cultural, and historical underpinnings that gave power to her personal connections. Without these underpinnings, her group members may have glossed over this scene that parallels and foreshadows the climactic scene that they later portrayed in their digital story. As Dahlia explained, the social negotiation of their book club discussions enabled her group members to understand this scene's significance.

Group members came to appreciate their diverse perspectives, which were filtered through their different cultures. Dahlia explained:

It was interesting for me that I would come from the book and the other students in my group weren't crying. Like I would be, "Did you realize what just happened?!" [in a crying voice]. And that was interesting for me, because I thought everybody was going to feel that way.

Dahlia was surprised that her group members had different aesthetic responses than her own. Thus, it was through social negotiation in book clubs that group members realized and respected their multiple perspectives on the text.

The expression of comprehension skills by group members was also socially negotiated. In their second book club meeting, they decided to sketch the houses in Buxton in their reading response notebooks based on the descriptions in the book. While keeping within those parameters, their sketches had impressive variety. For example, Catherine's house had a covered porch with rocking chairs, a white picket fence, and a flower garden. Mirjana imagined a larger plot of land, with a vegetable garden in the back, a dormered second floor, and curtains and shutters on the windows. Saleema had a cobbled walkway leading to a front stoop, a front lawn, and a few trees in front and in back of the house. Dahlia drew the main dirt road, and the row of houses that showed how she envisioned their proximity to each other, like a Levittown development. This variation highlights the interpretive work that occurs when readers move from one sign system to another (Siegel, 1995). In her interview, Dahlia stated, "it was just so interesting how we had different ideas of the houses or even how the front of everyone's house looked. And that was interesting to see our differences. We read the same book." Her quote again highlights the transactional nature of reading. Their sketches led to a rich discussion of the town of Buxton that caused them to return to the book for details and led to refinements of their envisioning.

For their information-seeking inquiry project (Lindfors, 1999), in addition to actual images and blueprints of both the exterior and interior of the homes, the group showed the church, the schoolhouse, and the barn. In addition, they discussed the governance of the settlement. In tracing Elijah's journey, the group used Google Earth to zoom in on that region of the world, and highlighted the route in blue. They showed the distance in miles, and discussed some of the hazards of travelling this route on horseback, as Elijah did. Group members later expressed the contribution this work made to their comprehension of the text. They discussed how it strengthened their background knowledge and sharpened their images of the setting and events in the book.

\section{Social Negotiation During Design Work}

Social negotiation especially came to the fore while the group designed their digital story. In the following excerpt, the group was negotiating which scenes to include. I was concerned 
about the possible length of their finished product, based on their plans so far, given the constraints of the assignment.

Dahlia: There's a scene that I really want to get in, where Elijah says, "I'm never gonna play the Abolitionists and Slavers game again...

Catherine: Oh, yeah, it's right here [referring to the passage in the text].

Dahlia: I think that that's so important, 'cause when I was reading the book, when I

heard, I heard that the kids were playing that game ["yeah"], I thought to myself, "they

have no idea ["yeah"], and he didn't realize "til the end, when he says, "playing an abolitionist is like playing an angel. And it's so sacred ["yeah"], so I think we should definitely touch on that part.

Catherine: That's p. 307.

Researcher: That might be a good place to end it [the PP show].

Saleema: We were going to keep going...

Mirjana: ...all the way to where Elijah brings Hope back with him to Buxton.

Catherine: [to group members] Do you think maybe the first scene would be enough?

Mirjana: That could be, after he learns, after the conversation where he learns who she

[Chloe] is...he explains who he is, then she explains who she is, and then there could be a quote at the bottom of him doing that thinking to himself, "I remember all the stories [inaudible]" [Catherine jots down these notes on their planning pages.] So, that would be Elijah's realization, right?

[They all turn to p. 307 and re-read that passage.]

Saleema: How're we going to show that thinking?

Catherine: Maybe him just standing there.

Dahlia: Standing there with maybe a bulb on top of his head. [The group chuckles at the image.]

Mirjana: You know how they show thinking in movies sometimes. Everything comes to a stand still; the music pauses. Then you know the person's turning inwards, within themselves. We could have some music in the background that we pause to show his realization.

Saleema: Let's see how that works.

[Catherine jots down more notes.]

This exchange shows this group's willingness to build on each other's ideas for meaning construction. In the excerpt, the group readily took up Dahlia's suggestion, as the discussion of the Abolitionist versus Slavers game had come up previously in their book group discussions. Recognizing the need to shorten their PowerPoint, they also readily took up my suggestion to end the movie with Elijah's realization. They then wrestled with the dilemma of how to show Elijah's thinking. They jokingly recalled the familiar icon of a light bulb on top of a person's head to show a revelation, before settling on cultural conventions in the familiar genre of movies: to simply use voiceover, with no soundtrack. Their deliberation showed the potential to construct meaning as they considered representing a challenging linguistic passage in a new sign system in the process of transmediation (Siegel, 1995).

\section{Taking on Roles}

The group also negotiated the roles they took on to complete the assignment. Mirjana, Catherine, and Dahlia discovered their mutual talents for drawing. Furthermore, Dahlia seemed adept at drawing Elijah, so she took on all the images that showed his face. Meanwhile, 
Catherine took on drawing the indistinct sacks that, as Elijah's eyes adjusted to the dark, gradually were revealed to be the captured slaves. Saleema was adept at finding and downloading sound effects. Mirjana was well-versed in movie features, and worked with Saleema to design the rolling credits at the end, which included such referential titles as "Director," "Producer," "Sound Effects," and "Hair \& Make-up." Based in her strong personal connections, Dahlia was determined to read the voice of Chloe. She was also well-versed in movie soundtracks, and helped identify the music that would fit the mood of their digital story, which Saleema then retrieved. Thus, group members were able to establish "meaningful forms of membership and empowering forms of ownership of meaning" (Wenger, 1998, p. 269). These relationships, relying on complementary skills, enabled the group to develop novel construction of their digital story (John-Steiner \& Meehan, 2000). Moreover, group members made "dense connections to communities outside its setting" (Wenger, p. 275). Saleema's husband gave her tutorials in downloading sounds and music; the group agreed to have Dahlia's nephew narrate Elijah's voice, since he was the same age as Elijah; and Dahlia's brother-in-law helped with sound editing.

\section{Design for Audience and Purpose}

Pervasive in the group's work was the sense of audience and purpose. All their design decisions seemed driven by their desire to present a representation of the text to their peers that honored the author's words and intentions. One of the group's first design decisions was to use hand drawings for their images. At first, they searched the Internet for images, but they could not find any continuity. The next week, Mirjana came in with a fully-realized drawing in her own sketch book of the image on the back cover of one of the editions of Elijah of Buxton that shows Elijah entering the stable at night (Figure 2). The group soon realized that Dahlia and Catherine also had drawing ability, and the group decided to rely on their own drawing abilities for their images. Mirjana explained: "We decided it was easier for us to get the feel across, everything that we wanted to show to our audience, through our pictures than finding things on the Internet." Her explanation expresses her commitment to purpose and audience. 
Figure 2. Mirjana's Original Sketch of Elijah Approaching the Stable.

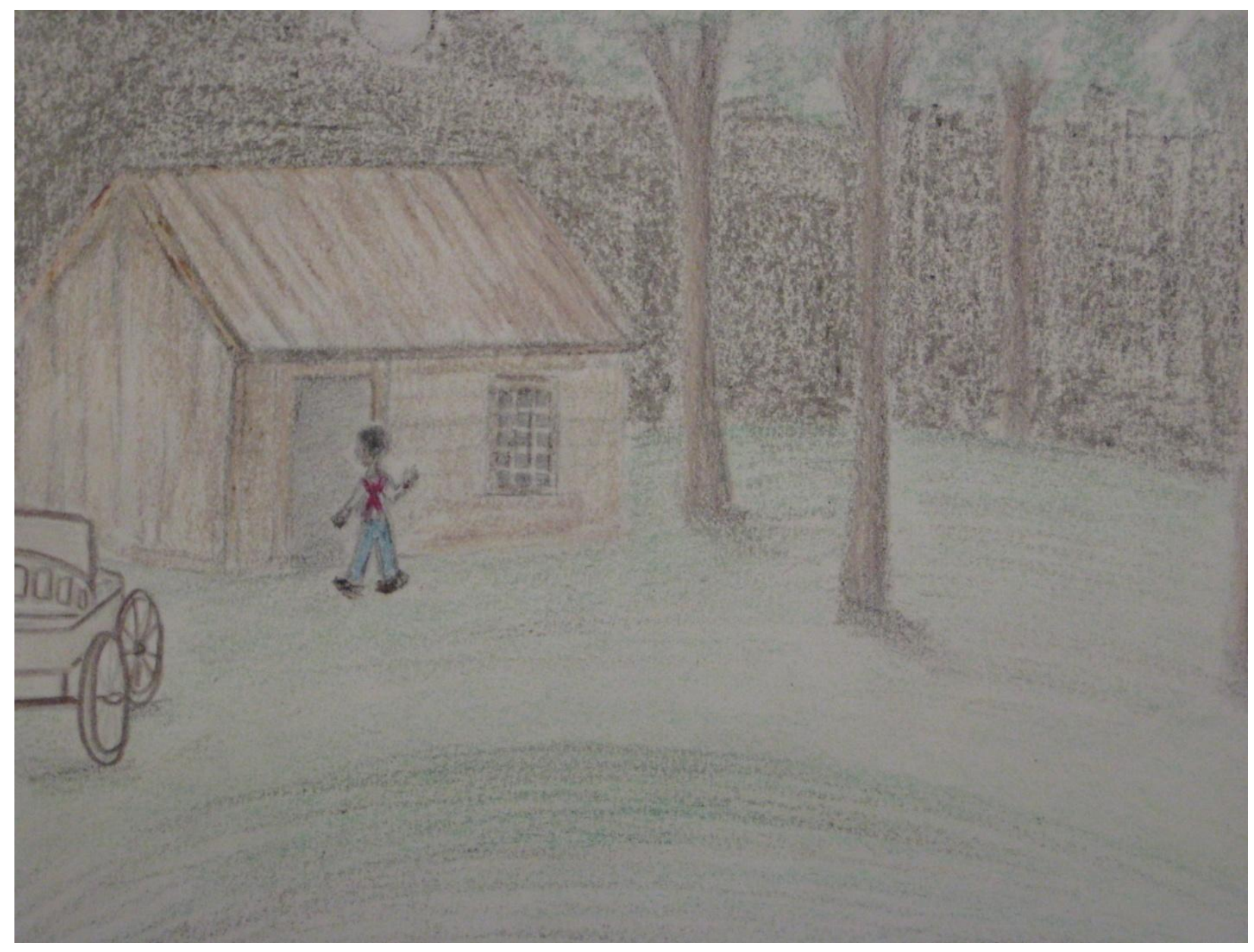

The group's commitment to audience and purpose, combined with the constraints of the assignment, guided them as well in what to include and what to omit. Even after they narrowed their focus to the scene they portrayed, they deliberately omitted details, such as Elijah knocking out the guard dog outside the stable with a stone before entering, or the drunken guard who was passed out inside the stable, or how Elijah gave water to the shackled slaves. The group relied on the conventions of movie trailers to guide their decisions. Mirjana explained: “... because of the limited time and we only had those four sessions, we just wanted to make sure that we get the most out of our presentation, our preview for our audience. So, there's definitely a lot that we left out." Getting the most out of their presentation meant clearly conveying the painful realization that Elijah had as the first free-born black boy in the Buxton settlement when he confronted, in Mirjana's words, "what real life is like in a world that still condones slavery in America."

\section{Affordances and Constraints in Design Work}

Their commitment to audience and purpose also guided their manipulation of the affordances of digital media. Near the start of their digital story, they have three slides that show Elijah racing on horseback to the stable, approaching (Mirjana's original image), and then entering the stable. The slide of Elijah on horseback shows the silhouette of a figure on a racing 
horse, with suspenseful music from "I Am Legend" and the sound of galloping. The slide of Elijah approaching the stable just has the noise of crickets and owls. The slide of Elijah entering the stable is particularly provocative. It shows just blackness, the sound of a creaking stable door, and the following voiceover from Elijah: "All I could see was black, and there was something else mixed up with the stable smell, somethin' that just wasn't sittin' right." Mirjana again explained these design decisions:

We wanted to go straight to the barn, that he's entering this dark barn. So, with the music in the background, and with the sound of the owls, and the picture of nighttime darkness, and entering a dark barn, that's what we wanted to convey to our audience. Without any text, I think we were able to get them to feel that nervousness, not knowing what's going to happen now, tension.

This explanation makes clear the group's commitment to audience and purpose. Moreover, the group was able to generate meaning in the sign systems of images and sounds without the use of print-based text. Their design work shows that " the world narrated' is a different world to 'the world depicted and displayed"' (Kress, 2003, p. 2).

Dahlia's humming in her portrayal of Chloe was one powerful example of the affordances of digital storytelling. In the book, Elijah describes the humming sounds that he heard when he entered the stable, which turn out to be Chloe humming to her baby. As a mother, Dahlia was able to imagine Chloe humming to her baby to calm her in the pitch darkness of the stable in this desperate situation. In the digital story, Dahlia hummed what sounded almost like a lullaby that she explained was based on "Amazing Grace." Dahlia knew that the song came out before the time that Elijah of Buxton took place. In fact, the song was written by John Newton (1725-1807), an English poet and clergyman, who was first a sailor who got caught up in the slave trade. The song expresses his redemption (Turner, 2002). "I didn't really hum the song, I just wanted that kind of feel... it's a song about slavery and Chloe was a slave, and it's a painful song." Dahlia used her own personal experience and her cultural knowledge to add a specific soundtrack that is never specified in the text. Her humming shows the generative power of working across sign systems. Her lullaby did not simply translate the content of the text, but also increased our understanding of it (Siegel, 1995).

Concurrently, the group experienced the constraints of the various modes in which they worked. In her interview, Catherine commented on Mirjana's depiction of the interior of the stable. "I envisioned a much bigger space." Catherine was also critical of her own depictions of the close-ups of Chloe ("I made her too light") and the African slave boy, who Elijah describes as crusted up from crying: "That was hard to draw. He was supposed to be all crusty, but he was a little boy, but I felt like I was drawing a man.” Or, though the group originally had animal sounds inside the stable, they later deleted them because they felt they cluttered the focus on Elijah's narration. They were articulating the anomalies or tensions that arose as the group manipulated the sign system of drawing and other modes on the expressive plane to convey the content of the story (Siegel, 1995).

\section{Tensions Across Modes of Expression}

Meaning construction out of a commitment to audience and purpose in design work was particularly apparent in the group's composing of the narrative script. They wanted to "stay true to the language" of the author, but also accommodate their audience's abilities to understand Elijah's and Chloe's dialects. As Mirjana aptly explained above, they also realized that other affordances of digital media could do some of the work of language. They were also confined in 
how much they could depict by the constraints of the assignment and of digital storytelling. As Catherine explained, they also did not want "to clutter the movie with too much narration." In addition, to stay true to the book, the group felt the need to adjust some of the language to accommodate Dahlia's nephew, who was narrating. Plus, Catherine said, "some of the language [in the book] just sounded funny when we read it out loud." These tensions presented anomalies between the content of the text and the expressive plane of their script, and guided their composition decisions. In Figure 3, I compare the original text to the script that the group composed.

Figure 3. A Comparison of Elijah of Buxton with the Group's Script.

\begin{tabular}{|l|l|}
\hline \multicolumn{1}{|c|}{ Group's Script } & \multicolumn{1}{|c|}{ Actual Text $^{3}$} \\
\hline $\begin{array}{l}\text { Slide 8: } \\
\text { Elijah: I realized they were men. Their } \\
\text { eyes were all on me and they were looking just } \\
\text { as scared and confused and surprised 'bout } \\
\text { seeing me as I was 'bout seeing them. }\end{array}$ & $\begin{array}{l}\text { The rest of 'em were men and they } \\
\text { waren't wearing nothing atall, not even a } \\
\text { rag. Their ankles were covered with the } \\
\text { same kind of thick iron shackles as the } \\
\text { woman's. Their eyes were all on me and they } \\
\text { were looking just as scared and confused and } \\
\text { surprised 'bout seeing me as I was 'bout seeing } \\
\text { them. }\end{array}$ \\
$\begin{array}{l}\text { Slide 10: } \\
\text { Elijah: I now realized what the odd smell } \\
\text { in the stable was; it was fear. It was the smell } \\
\text { of four growned folks and one baby that were } \\
\text { afraid. }\end{array}$ & $\begin{array}{l}\text { I pulled my hand away and all the sudden } \\
\text { I knowed what the odd smell in the stable } \\
\text { wast was fear. It was the smell of five } \\
\text { growned folks and one baby that were } \\
\text { afeared of everything. }\end{array}$ \\
\hline
\end{tabular}

In slide 8, we see the back of Elijah's head as he looks at three non-descript bundles on the ground (Figure 4). In slide 10, we again see the back of Elijah's head as he now distinguishes the bundles as two men and a boy who are sitting on the ground, naked, with their arms and legs shackled to the wall (Figure 5). Whereas in the book, Elijah gradually distinguishes the four sacks on the ground from the four-armed bundle that turns out to be Chloe with her baby, the digital story omits these details. The script then builds coherence by changing the language from "The rest of them were men..." to "I realized they were men..." In addition, in the sound effects of slide 9 we hear the rattling of chains, and slide 11 shows the back of Elijah's head as he looks at the naked woman, Chloe, who is shackled at the ankles, with the baby wrapped in a rag across

\footnotetext{
${ }^{3}$ I used this font to show where the text differed in the book, this font to show where the texts were the same, and this font to show where the group changed the text in the script from the original.
} 
her chest (Figure 6). The script then is more efficient by omitting the details, “... and they waren't wearing nothing atall, not even a rag. Their ankles were covered with the same kind of thick iron shackles as the woman's," since these are details the sound effects and the images provide. The digital story also omits the details about Elijah giving them water with a dipper from a bucket. The script again builds coherence by omitting the detail of Elijah pulling his hand away from the African boy, and changing the language to "I now realized..." In the picture, Catherine only drew three bundles, which she was better able to fit in the frame, so rather than confuse the audience, she changed the number of men from four to three. She also changed "... afeared of everything” to the more familiar word afraid, which was more comprehensible to the audience and easier for Dahlia's nephew to read.

Thus, as readers, the students expressed reading skills such as determining importance, synthesis, and interpretation. As writers, they had to be inventive to solve the anomalies from the content plane to the expressive plane of meaning (Siegel, 1995). They acted as remakers of text in a communicational environment. They "transform[ed] the existing resources of the language to serve the directions" of their social intentions (Kress, 2003, p. 75). Through social negotiation, the entire script accommodated the audience, the purpose, and the participants in the designing of this digital story.

Figure 4. Elijah Sees Shapes Against the Wall of the Shed.

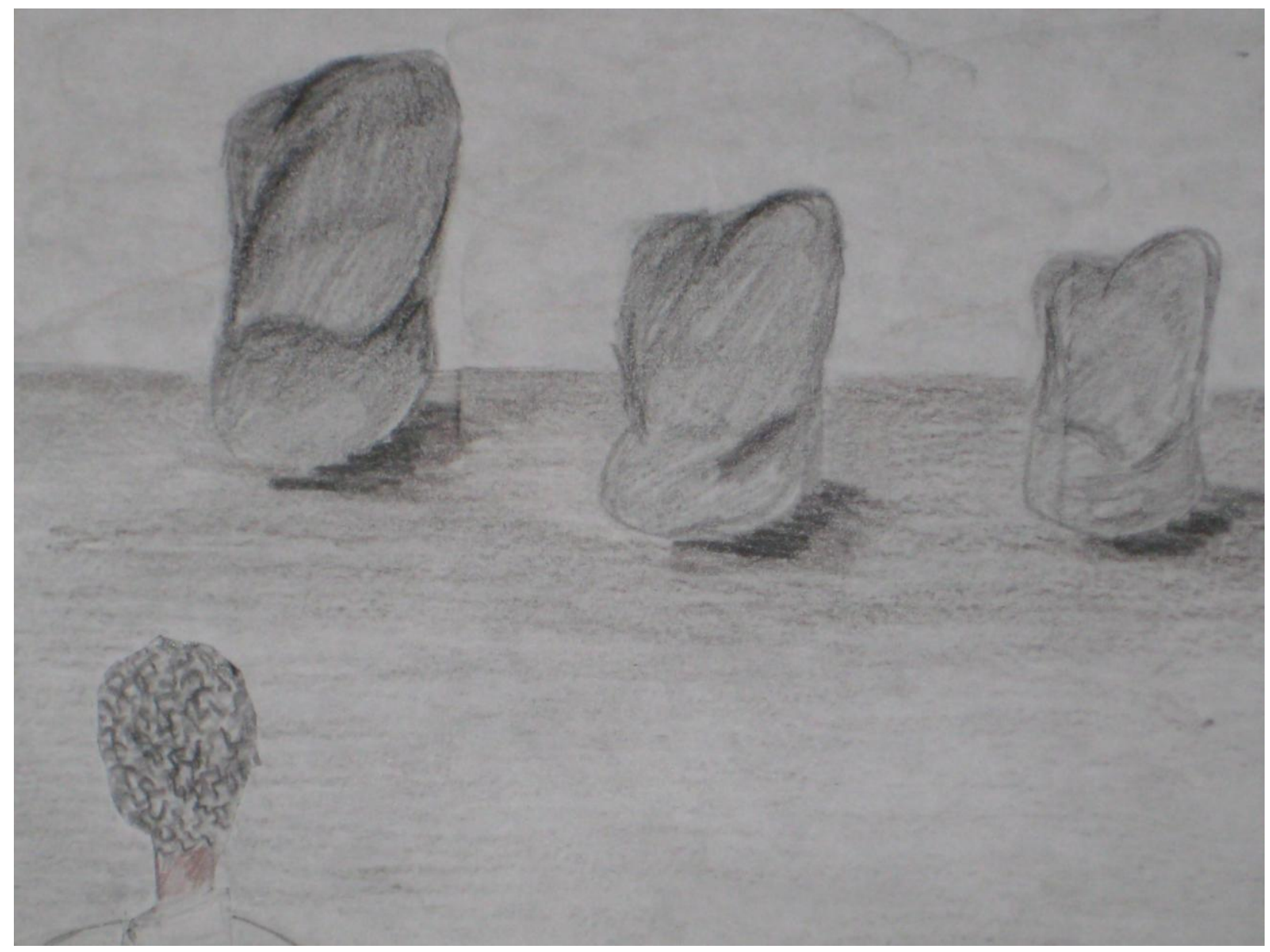


Figure 5. Elijah Recognizes the Shapes as Slaves.

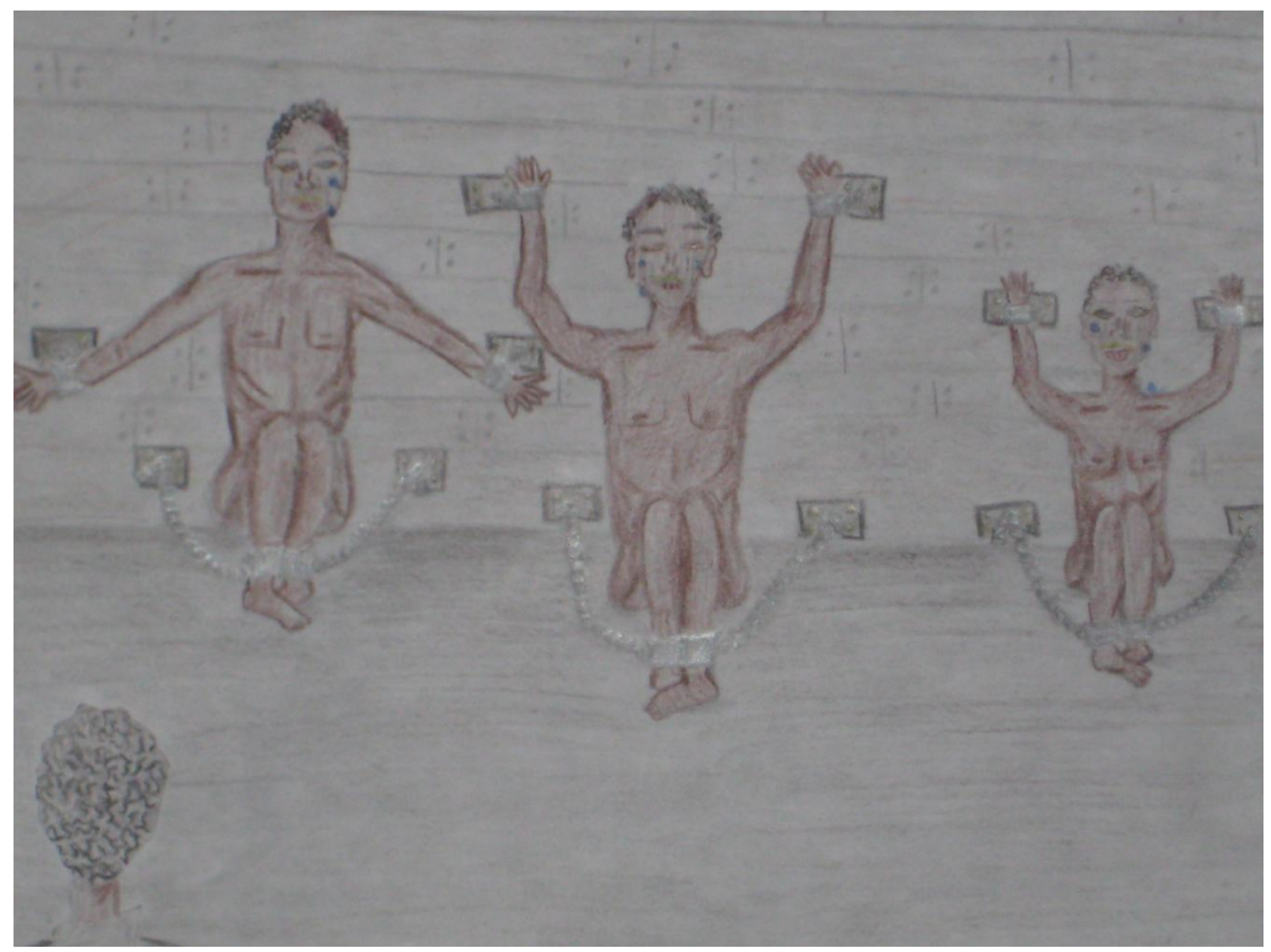


Figure 6. Elijah Meets Chloe and Her Baby.

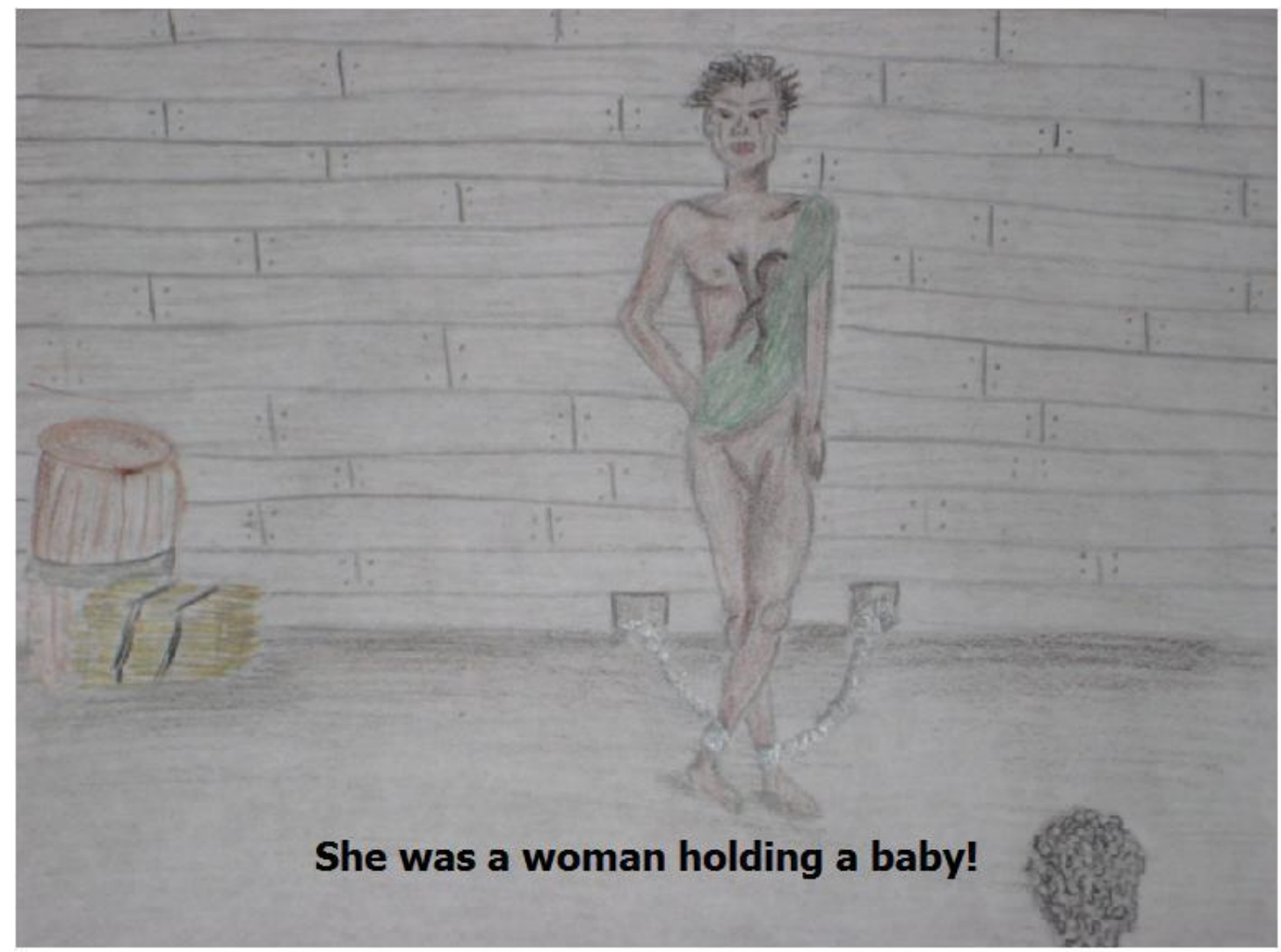

Expanded Understandings of Texts, Readers, and Response

By the end of this project, the participants expressed far more complex understandings of texts, readers, and response. Looking across the interviews with all seven focal students, they emphasized the social negotiation of meaning, valuing differences, and learning from multiple perspectives, which are filtered through culture. One participant aptly perceived a text as "not only reading words; it's reading images, people's body language, symbols." Moreover, the participants now endorsed multiple modes of expression in response to reading, relying on each person's skill sets and resources. They described showing understanding through such modes as facial expressions, our bodies and voices, art, and building materials, in addition to digital media. Dahlia referred to having multiple opportunities "to manipulate a book." By this, Dahlia went on to explain, she meant the many transactional strategies that we explored in our reading response notebooks. Participants also discussed building connections through integrating literacy practices across the curriculum or engaging in information-seeking inquiry. These were all practices that the participants now firmly endorsed for the teaching of children.

The participants also expressed changes in their reading identities. Dahlia stated: 
I wasn't much of a reader before this class. And, so that was always a worry, was how I would be a good literacy teacher to my students because I don't read much and I don't have a relationship with reading. But now, after reading Elijah of Buxton and The Kite Runner (we also had in a book club [in another professor's class]), I was really able to fall in love with reading. It wasn't like a chore or a task that I had to get done. I really, I fell in love with it, and to see what we could do: we could do so much with our reader's notebook and we could do so much with just talking about the text with people.

Dahlia expressed what several other participants also stated: that the work of this project did not feel like the usual work they had experienced in their schooling. Dahlia and others went so far as to call this work "fun." They said that Lucia and I gave them uninterrupted time to work on their project, we trusted them to get the work done, and supported them as needed. Thus, it seems that "the design of forms of participation [provided] entry into a practice and let the practice itself be its own curriculum" that led to participants' new understandings (Wenger, 1998, p. 265).

\section{Discussion}

The centrality of design work in this research project enabled sociocultural and multimodal engagements with text that deepened the students' meaning-making. These strong engagements with text then expanded their conceptions of texts, readers, and response. The design of this project seemed to provide enough robustness to enable learning to happen. Wenger (1998) defines design as "a systematic, planned, and reflexive colonization of time and space in the service of an undertaking" (p. 228). He emphasizes that learning occurs as the result of the social negotiation of meanings in these undertakings. Wells (2000) states, "learning is an outcome that occurs because the making requires the student to extend his or her understanding in action" (p. 64). In these design contexts, "teachers and the instructional materials become resources for learning in much more complex ways than through their pedagogical intentions" (Wenger, 1998, p. 267). He advocates "[minimizing] teaching so as to maximize learning," by enabling the processes of negotiation of meaning to occur. This might be what the participants in this study meant by the project was "fun." The technology teacher and I and our instructional materials became resources as students took charge of their own learning through the negotiation of meaning in their design work. Their ownership of meaning enabled experiences that changed students' understandings of themselves as learners. Dahlia aptly expressed the change of her reading identity through her engagement in this project. Moreover, by coordinating multiple perspectives, the group developed flexibility for application in diverse contexts (John-Steiner \& Meehan, 2000), as they confidently expressed their newfound abilities to implement many of the practices in this project with children.

The power of design enabled learners to realize, in Catherine's words, "the multiple layers of literacy." The New London Group (1996) describes three elements to design: available designs ("resources for meaning; available designs of meaning"), designing ("the work performed on/with available designs in the semiotic process"), and the redesigned (the products of design work) (p. 77). They explain, "designing always involves the transformation of Available Designs; it always involves making new use of old materials" (p. 76). Moreover, the redesigned produces "new meaning, something through which meaning-makers remake themselves" (p. 76). At one and the same time, the redesigned relies on "historically and culturally received patterns of meaning" and "is the unique product of human agency: a transformed meaning" (p. 76). The design work of the Elijah of Buxton group that this paper describes shows making new use of old materials, such as using drawings in digital media. The 
group certainly relied on historically and culturally received patterns of meaning, such as Dahlia's use of "Amazing Grace." The group's particular mix of people enabled a unique product of human agency: a transformed product.

The design provided the strong sense of audience and purpose, which justified the participants' intense activity (Vygotsky, 1978, p. 103). In their activity, we saw an intellectual interdependence that enabled creative production that went beyond the scope of what would have been possible for one of the group members alone. Even as group members assumed roles, they did not have a static division of labor. Rather, they engaged in dynamic interactions that enabled mutual appropriation of different ways of thinking (John-Steiner \& Meehan, 2000). This process explains their emphasis on multiple perspectives in their expanded visions of literacy. Welsh (2000) states: "it is by attempting to make sense with and for others that we make sense for ourselves" (p. 58). Welsh posits that the strong sense of audience and purpose in worthwhile and intrinsically motivating activities enables knowledge building as writers, through social negotiation, try "to negotiate the likely response of the envisaged audience and [carry] on a dialogue with the text being composed" (p. 77). This was certainly the case as we saw the composing process for the script by the Elijah of Buxton group.

The group also showed social and symbolic flexibility and adaptation as they orchestrated signifying structures in multiple sign systems (Siegel, 2006). This finding supports the literature on learners' generative and interpretive capacities when they engage in multimodal responses to texts (Ballentine \& Hill, 2000; Clyde, 2003; O’Brien, 2001; Short, Kauffman, Kahn, 2000; Whitin, 1996; 2005; Wilhelm, 2008). In addition, the results support the value of the multimodal affordances of digital media for students' meaning making (Larson, 2008; O'Brien, 2001; Whitin, 2009). The use of digital media enabled symbol weaving in the group's deliberate layering of sound effects, text, music, voiceovers, layout, color, and other design elements for expanded and transformed meanings (Whitin, 2009). Moving across sign systems created anomalies that the group had to bridge to generate meaning, in a process of transmediation, such as how to show Elijah's epiphany in the digital story. "The absence of a ready-made link between the content and expression planes of two different sign systems creates an anomaly that sets generative thinking in motion" (Siegel, 2006, p. 70), which represents learning (Jewitt \& Kress, 2003, p.13).

The findings also show the social and cultural underpinnings of the group's multimodal work. In other words, their work as designers "reflect[ed] and track[ed] the values, structures and meanings of the social and cultural world of the meaning-maker[s] and of the socio-cultural group in which they [participated]" (Kress, 2003, p. 40). Learning occurred as they imbued existing forms and resources with new meanings, creating a new text out of the old. Moreover, their multimodal production was based in assessing "what is needed in this situation now, for these conditions, these purposes, this audience" (p. 49), which Kress terms design. Thus, multimodal theory affirms the robustness of design to enable learning in sociocultural contexts.

\section{Limitations}

This study shows that socially-constructed digital storytelling can be a powerful form to expand students' understandings of texts, readers, and response. The affordances of digital storytelling enable the layering of symbols across distinct modes for deeply interpretive work (Siegel, 1995, 2006). Burgess (2006) posits that "digital storytelling is an example of creativity in the service of...the affective practice of the social," (p. 210), and thus an effective source of communication. Perhaps because of its temporal sequence and the primacy of narration that 
"recaptur[es] the warmth of human intimacy" (p. 210), it favors, as this study shows, an aesthetic response to literature. This kind of response seemed to be a strong fit with the deeply meaningful historical fiction that the students read. However, Rosenblatt (1994) reminds us that an aesthetic stance is not always what the transaction calls for, nor should it be more valued than an efferent stance. One limitation of this study then is that socially-constructed digital storytelling seems to favor an aesthetic stance. Moreover, we might wonder if digital storytelling would be a good fit as a form of response for certain genres, such as non-narrative nonfiction. One response to this limitation is to conduct a rich array of transactional reading responses that include efferent stances alongside socially-constructed digital storytelling for narrative texts, as I did in this study. A second response is to provide a rich array of choices for digital multimodal responses as Larson (2008) did in her study. Thus, working in groups, her students chose digital responses that matched their reading stances for the common class text and that they envisioned for potential implementation in their future classrooms.

The small sample and limited time frame of this study's design prevents claims of transformation. The findings suggest more case studies with future cohorts to see what patterns emerge across contexts. In addition, the findings suggest longitudinal studies that document how pre-service teachers implement their new understandings of texts, readers, and response with their own elementary school students as they enter the teaching profession.

\section{Implications}

Graduate students bring their histories as students with them which often include narrow conceptions of literacy that privilege verbocentric modes of expression and perceptions of reading and writing as solitary acts. They then carry these conceptions into their work with children, even when these practices conflict with their belief statements. It is imperative then that teacher educators provide alternative models by designing authentic joint activities for collaborative meaning making. Moreover, digital media seem to provide affordances for multimodal production that is greater than the sum of their parts. As Dahlia stated, "I've learned that, even though you've taught us this, it's one thing being taught something, but it's another thing to actually do it. Like, I know that it's possible." As Wenger (1998) states, "it is as learners that we become educators" (p. 277). Knowing what's possible in literacy learning has situated these pre-service teachers to bring these practices to, and thus better meet the needs of, the diverse students they will teach.

\section{References}

Ballentine, D. \& Hill, L. (2000). Teaching beyond “once upon a time.” Language Arts, 78 (1), 11-20.

Brass, J. J. (2008). Local knowledge and digital movie composing in an after-school literacy program. Journal of Adolescent and Adult Literacy, 51 (6), 464-473.

Burgess, J. (2006). Hearing ordinary voices: Cultural studies, vernacular creativity and digital storytelling. Continuum: Journal of Media \& Culture Studies, 20 (2), 201-214.

Charmaz, K. (2000). Grounded theory: Objectivist and constructivist methods. In N. Denzin \& Y. S. Lincoln (Eds.), Handbook of qualitative research $\left(2^{\text {nd }}\right.$ ed., pp. 509-536). Thousand Oaks, CA: Sage.

Clyde, J. A. (2003). Stepping inside the story world: The subtext strategy - a tool for connecting and comprehending. The Reading Teacher, 57 (2), 150-160. 
Dyson, A. H. \& Genishi, C. (2005). On the case: Approaches to language and literacy research. New York: Teachers College Press.

Fountas, I. C. \& Pinnell, G. S. (2001). Guiding readers and writers, grades 3-6. Portsmouth, NH: Heinemann.

Glaser, B. G. \& Strauss, A. L. (1967). The discovery of grounded theory: Strategies for qualitative research. New York: Aldine.

Harste, J., Woodward, V., \& Burke, C. L. (1984). Language stories and literacy lessons. Portsmouth, NH: Heinemann.

Hull, G. A. \& Katz, M. L. (2006). Crafting an agentive self: Case studies of digital storytelling. Research in the Teaching of English, 41 (1), 43-81.

Jewitt, C. \& Kress, G. (eds.) (2003). Multimodal literacy. New York: Peter Lang.

John-Steiner, V. P. \& Meehan, T. M. (2000). Creativity and Collaboration in Knowledge Construction. In C. D. Lee \& P. Smagorinsky (Eds.), Vygotskian Perspectictives on Literacy Research (pp. 31-48). New York: Cambridge University Press.

Kress, G. (2000). Design and Transformation. In B. Cope \& M. Kalantzis (Eds.), Multiliteracies: Literacy learning and the design of social futures (pp. 153-161). London: Routledge.

Kress, G. (2003). Literacy in the new media age. London: Routledge.

Kress, G., \& van Leeuwen, T. J. (2001). Multimodal discourse: The modes and media of contemporary communication. London: Arnold.

Larson, L. C. (2008). Electronic reading workshop: Beyond books with new literacies and instructional technologies. Journal of Adolescent \& Adult Literacy, 52 (2), 121-131.

Lave, J. \& Wenger, E. (1992). Situated learning: Legitimate peripheral participation. Cambridge: Cambridge University Press.

Leu, D. J., O'Byrne, W. I., Zawilinski, L., McVerry, J. G., Everett-Cacopardo, H. (2009). Expanding the new Literacies Conversation. Educational Researcher, 38 (4), 264-269.

Lindfors, J. W. (1999). Children's inquiry. New York: Teachers College Press.

Merriam, S. B. (2001). Qualitative research and case study applications in education: Revised and expanded from case study research in education. San Francisco: Jossey-Bass.

Miles, M. B., \& Huberman, A. M. (1994). Qualitative data analysis: An expanded sourcebook (2nd ed.). Thousand Oaks, CA: Sage.

O'Brien, D. (2001). "At risk" adolescents: Redefining competence through the multiliteracies of intermediality, visual arts, and representation. Reading Online, 4 (11).

Ohler, J. (2005/2006). The world of digital storytelling. Educational Leadership, 63 (4), 44-47.

Probst, R. E. (1994). Reader-Response Theory and the English curriculum. The English Journal, 83 (3), 37-44.

Raphael, T. E. \& McMahon, S. I. (1994). "Book Club": An alternative framework for reading instruction. The Reading Teacher, 48, 102-116.

Rosenblatt, L. (1994). The reader, the text, the poem: The transactional theory of the literary work. Carbondale: Southern Illinois University Press.

Short, K. B. \& Harste, J. C. (1986). Creating classrooms for authors and inquirers. Portsmouth, NH: Heinemann.

Short, K. G., Kauffman, G., Kahn, L. H. (2000). "I just need to draw": Responding to literature across multiple sign systems. The Reading Teacher, 54 (2), 160-171.

Siegel, M. (1995). More than words: The generative power of transmediation. Canadian Journal of Education, 20 (4), 455-475.

Siegel, M. (2006). Rereading the signs: Multimodal transformations in the field of literacy 
education. Language Arts, 84 (1), 65-77.

Smolin, L.I., \& Lawless, K.A. (2003). Becoming literate in the technological age: New responsibilities and tools for teachers. The Reading Teacher, 56 (6), 570-577.

Skinner, E. N. \& Hagood, M. C. (2008). Developing literate identities with English language learners through digital storytelling. The Reading Matrix, 8 (2), 12-38.

Stake, R. (2000). Case studies. In N. Denzin \& Y. S. Lincoln (Eds.), Handbook of qualitative research $\left(2^{\text {nd }}\right.$ ed., pp. 435-454). Thousand Oaks, CA: Sage.

Sylvester, R. \& Greenidge, W. (2009). Digital storytelling: Extending the potential for struggling writers. The Reading Teacher, 63 (4), 284-295.

Turner, S. (2002). Amazing Grace: The story of America's most beloved song. New York: HarperCollins.

Vygotsky, L. S. (1962). Thought and language. Cambridge, MA: M.I.T. Press.

Vygotsky, L. S. (1978). Mind in society. Cambridge, MA: Harvard University Press.

Wells, G. (2000). Dialogic inquiry in education. In C. D. Lee \& P. Smagorinsky (Eds.), Vygotskian Perspectictives on Literacy Research (pp. 51-85). New York: Cambridge University Press.

Wenger, E. (1998). Communities of practice: Learning, meaning, and identity. New York: Cambridge University Press.

Whitin, P. E. (1996). Exploring visual response to literature. Research in the Teaching of English, 30 (1), 114-140.

Whitin, P. E. (2005). The interplay of text, talk, and visual representation in expanding literacy interpretation. Research in the Teaching of English, 39 (4), 365-397.

Whitin, P. E. (2009). "Tech-to-Stretch": Expanding possibilities for literature response. The Reading Teacher, 62 (5), 408-418.

Wilhelm, J. D. (2008). "You gotta be the book": Teaching engaged and reflective reading with adolescents ( $2^{\text {nd }}$ ed.). New York: Teachers College Press.

Young, CA., \& Bush, J. (2004). Teaching the English language arts with technology: A critical approach and pedagogical framework. Contemporary Issues in Technology and Teacher Education [Online serial], 4 (1).

\section{Children's Literature Cited}

Bridges, R. (1999). Through my eyes. New York: Scholastic.

Choldenko, J. (2004). Al Capone does my shirts. New York: G. P. Putnam's Sons.

Curtis, C. P. (2007). Elijah of Buxton. New York: Scholastic.

Earley, T. (2000). Jim the boy. Boston, MA: Little Brown.

Hesse, K. (1998). Just Juice. New York: Scholastic.

Keats, E. J. (1962). The snowy day. New York: Scholastic.

Krumgold, J. (1953). ... and now Miguel. New York: HarperTrophy.

Polacco, P. (1998). Thank you, Mr. Falker. New York: Philomel.

Porter, T. (2007). Billy Creekmore. New York: HarperCollins.

Wagner, J. (1969). J.T. New York: Bantam Doubleday Dell.

Woodson, J. (2001). The other side. New York: G. P. Putnam's Sons. 


\section{Author Biography}

Ted Kesler is an assistant professor in the Elementary and Early Childhood Department of Queens College, CUNY. He currently teaches graduate level courses in foundations of literacy and children's literature, in addition to supervising students in their field placements. His research interests include: the influence of high-stakes testing on literacy instruction, multimodal responses to literature, critical media literacy, and issues in children's literature. tkesler@qc.cuny.edu.

Ted would like to thank Maureen Kendrick and the anonymous reviewers for their helpful suggestions on an earlier version of this paper. 


\section{Appendix A}

Our Digital Movie Checklist

\section{Digital Movie Checklist}

Names:

Our Book Club Text:

Digital Movie Title:

Your digital movie should include the following things:

Strong dramatic scene(s) from your book club book.

A clear theme.

Music and sound effects that add to the mood of your story (with appropriate timing).

Narration that builds your story while staying true to the text.

Text that enhances your slides.

Visual images that reflect the setting and mood of the story (with appropriate timing).

Transitions that add to the mood and theme of your story and builds coherence.

$\square$ Overall design that adds to the mood and theme of your story and builds coherence.

$\square$ Credits that cite all audio, video, graphic resources.

Credits to group members.

In addition, make sure that:

The presentation is approximately 5 minutes.

You saved your work on your flashdrive.

You handed in all your storyboards and notes for the project. 
Appendix B

Digital Movie Storyboard Template.

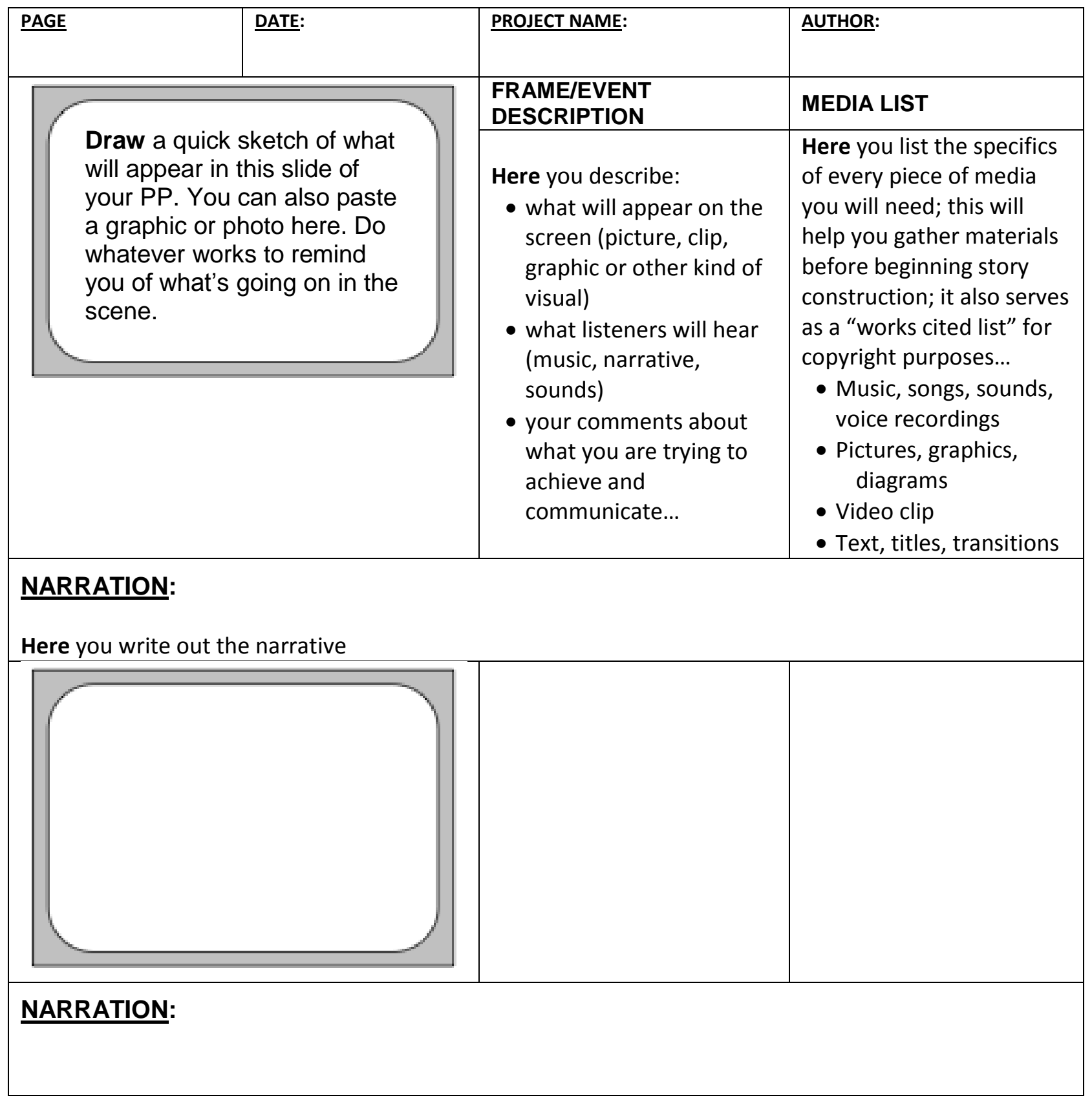




\section{Appendix C}

Interview Questions with Focal Students

1. Take me through your composing process for your digital storytelling work.

2. What skills did you use in this project?

3. What did you learn about literacy from your book club experience?

4. What is literacy for you now?

5. What did you learn about literacy from this project?

6. How has your thinking about literacy changed as a result of this project?

7. What were some of the strengths and difficulties of this project?

8. How did your work on this project inform your work as a literacy teacher?

9. What might be some of the challenges of using technology in the teaching of literacy with children? 